\title{
HEALTH BELIEF MODEL ON THE FACTORS ASSOCIATED WITH THE USE OF HPV VACCINE FOR THE PREVENTION OF CERVICAL CANCER AMONG WOMEN IN KEDIRI, EAST JAVA
}

\author{
Rosi Rizqi Nugrahani1', Uki Retno Budihastuti²), \\ Eti Poncorini Pamungakasari3) \\ ${ }^{1)}$ Masters Program in Public Health, Sebelas Maret University \\ 2)Department of Obstetrics and Gynecology, Dr. Moewardi Hospital, \\ Surakarta \\ 3)Department of Public Health, Faculty of Medicine, Sebelas Maret University
}

\begin{abstract}
Background: Cervical cancer is a deadly disease with high incidence rates in the world and in Indonesia. In Kediri, East Java, there were 33 women who had cervical cancer in 2016, 3 of them died. Cervical cancer is caused by type 16 and type 18 Human Papilloma Viruses (HPV). This disease can be prevented by the application of HPV vaccine. This study aimed to examine factors associated with the use of HPV vaccine for the prevention of cervical cancer among women in Kediri, East Java, using health belief model (HBM).

Subjects and Method: This study was an analytic observational with case control design. It was conducted in Kediri, East Java, from February 10 to March 10, 2017. A sample of 120 women consisting of 40 women who had used HPV vaccine and 80 women who had not used HPV vaccine, were selected for this study by fixed disease sampling. The dependent variable was use of HPV vaccine. The independent variables included perceived susceptibility, perceived severity, perceived benefit, perceived threat, perceived barrier, and cues to action. The data were collected by a set of pretested questionnaire. Logistic regression was employed for data analysis.

Results: The use of HPV vaccine was associated with perceived susceptibility $(\mathrm{OR}=0.79 ; 95 \% \mathrm{CI}=0.23$ to $2.70 ; \mathrm{p}=0.710)$, perceived severity $(\mathrm{OR}=5.19$; $95 \% \mathrm{CI}=1.30$ to $20.66 ; \mathrm{p}=0.019)$, perceived threat $(\mathrm{OR}=1.04 ; 95 \% \mathrm{CI}=0.32$ to $3.35 ; \mathrm{p}=0.942)$, perceived benefit $(\mathrm{OR}=1.33 ; 95 \% \mathrm{CI}=0.40$ to $4.38 ; \mathrm{p}=$ $0.638)$, perceived barrier $(\mathrm{OR}=0.42 ; 95 \% \mathrm{CI}=0.14$ to $1.27 ; \mathrm{p}=0.126)$, and cues to action $(\mathrm{OR}=5.90 ; 95 \% \mathrm{CI}=1.30$ to $26.74 ; \mathrm{p}=0.021)$.

Conclusion: The use of HPV vaccine is associated with perceived susceptibility, perceived severity, perceived threat, perceived benefit, perceived barrier, and cues to action. Constructs in health belief model can be used to predict the use of HPV vaccine.
\end{abstract}

Keywords: health belief model, use of HPV vaccine

Correspondence: Rosi Rizqi Nugrahani. Masters Program in Public Health, Sebelas Maret University, Jl. Ir. Sutami 36 A, Surakarta, Central Java.

Email: rchochia@yahoo.com. Mobile: +6285735150606. 